and the large-scale migration, indentured and informal, of labor to mines and plantations in South Asia and overseas are likewise vast and relatively unexplored territory for historians. The conference's exploration of these and other themes within the context of global and local linkages was an excellent idea. The theoretical focus blurred sometimes, but this was partly because three days was not long enough to discuss the wide range and dense texture of the contributions.

The conference ended with a proposal to establish an Indian Labour Studies Association which would publish a newsletter and organize an ongoing series of workshops. The term "studies" rather than "history" was used in order to accommodate inquiries into contemporary movements and issues. Jan Lucassen, head of the IISG's Research Department, welcomed the proposal with an assurance of support and suggested that European labor studies would benefit greatly from an engagement with the methodological freshness and substantive empirical work which characterize South Asian labor studies. The founding meeting of this new organization will be held in India on December 15 and 16, 1996.

\title{
Aftermath: The Transition from War to Peace in America
}

\section{After World War II}

\author{
Roger Horowitz \\ Hagley Museum and Library
}

World War Two was one of the great watershed events in American history. comparable only to the American Revolution and the Civil War. It was a formative experience for the sixteen million men and women who entered the armed forces and the far greater numbers who were touched by the wal experience on the home front.

However, the legacy of the war in postwar America has been taken for granted, rather than carefully analyzed and explained. To bring greates attention to this critical transition, the Center for the History of Business. Technology, and Society at the Hagley Museum and Library sponsored $a$ conference, "Aftermath: The Transition from War to Peace in Americ After World War II," on October 26 and 27, 1995. A grant from the Delaware Humanities Forum provided partial funding for the event.

The conference opened with a keynote address by Alan Brinkley. "Legacies of World War II." Brinkley emphasized that the hopes inspirec by the war were circumscribed by the competing agendas of different sec. 
tors of the American population. Among liberal intellectuals such as Reinhold Niebuhr, hope for a renewed Wilsonian idealism were overshadowed by fears of mob rule (a reflection of the success of fascism) and of an atomic war that could obliterate modern civilization.

Four panels focused on aspects of the transition from war to peace. The first session, titled "The Soldiers Come Home to Dixie," explored the political and racial conflicts in southern states that accompanied the return of black and white soldiers to their homes. Jennifer Brooks (University of Knoxville) examined the political conflicts in the South that erupted when black and white veterans sought to extend the struggle for democracy to the postwar home front. She carefully identified the complexity of responses by veterans, especially divisions over altering the South's racial policies, but emphasized that the net impact was to modernize southern politics while maintaining Jim Crow segregation. David Onkst (American University) documented thoroughly how the efforts of black veterans to receive the benefits of the GI bill were consistently frustrated by state political machines' control over these programs and their determination to maintain the racial status quo. Jane Levey (Yale University) drew on the voices of black veterans to show how the war transformed their notions of their rights as citizens and stimulated struggles immediately after the war to secure full civil and political rights.

"Defining the Postwar Welfare State" concentrated on the obstacles to expanding the provision of social benefits after the war. Colin Gordon (University of Iowa) identified the immense obstacles to the development of national health care after the war because of fragmentation among its proponents and the high level of organization and resources available to opponents, especially the American Medical Association and private insurance companies. Meg Jacobs (University of Virginia) attributed the decline of grassroots sentiment for price controls and the Office of Price Administration after the war to the inability of the federal government to make goods available at reasonable prices. James Atleson (University of Buffalo), saw the restrictions imposed on the labor movement after the war flowing from the language of sacrifice and national unity that characterized the discourse of labor relations during wartime. In a stimulating comment, Ira Katznelson (Columbia University) observed that the power of retrograde southern Democrats within the national party seemed to be the greatest obstacle to establishing a stronger welfare state after the war.

Another panel focused on the complex efforts to define relations between government and business in the immediate postwar period. Jennifer Klein (University of Virginia) argued that scholars had neglected the enormous expansion of the private welfare state after the war. Her study of the explosion of commercial health insurance documented business dominance of this process, despite the nominal involvement of labor unions in the incorporation of these programs into employee benefit packages. David Hart (Harvard University) revisited the struggles over technology policy 
after the war. He contended that federal involvement continued into the postwar years despite the apparent hegemony of Vannevar Bush's approach, which emphasized control by the private sector. Allen Kaufman (University of New Hampshire) argued that the roots of the militaryindustrial complex were laid during the war because of the enormous effectiveness of the contract system and the power of military procurement officers in obtaining sufficient coordination among private firms to produce armaments and other material for the war effort.

The final session shifted the discussion to the war's influence on postwar culture. During the break preceding the panel, Tim Berg (Indiana University) piqued the audience's interest in his paper by playing recordings of music by musicians such as Chuck Berry, who had first recorded with Chess Records. His paper explained that the postwar success of Chess and other small record labels reflected the combined impact of black migration to cities during the war, the technological advances of cheaper recording equipment and the $45 \mathrm{rpm}$ record, and the capacity of small record companies to cater to the tastes of particular groups. Elizabeth Hillman (US Air Force Academy), contrasted "dress blues" of women in the military during World War Two, which combined attractiveness with utility, to the promotion of frivolous dresses after the war, which emphasized female attractiveness and domesticity at the expense of career. Jeffrey Meikle (University of Texas) demonstrated how the wartime development of new plastics allowed manufacturers to promote postwar plastic consumer products as both visually pleasing and easy to clean-what he dubbed "damp cloth utopianism."

A particularly refreshing aspect of the conference was the interaction among scholars based in different disciplines but all interested in the tremendous impact of World War Two on the immediate postwar period. While there are no plans to publish the conference proceedings, doubtless many of these papers will appear in academic journals in the next few years.

\title{
International Congress for Historians
}

\author{
Adelheid von Saldern
}

Universität Hannover

This meeting, held in Montreal (August 27-September 3, 1995) foregrounded sessions on "major themes" like "nations, peoples, and state 